\title{
Processing Optimization and Physicochemical Characteristics of Collagen from Scales of Yellowfin Tuna (Thunnus albacares)
}

\author{
Yuna Han ${ }^{1}$, Ju-Ryun Ahn ${ }^{1}$, Jin-Wook Woo ${ }^{2}$, Cheol-Kyun Jung ${ }^{1}$, \\ Sueng-Mock Cho ${ }^{3}$, Yang-Bong Lee ${ }^{1}$ and Seon-Bong $\mathrm{Kim}^{1}{ }^{*}$ \\ ${ }^{1}$ Department of Food Science and Technology/Institute of Food Science, \\ Pukyong National University, Busan 608-737, Korea \\ ${ }^{2}$ Food R\&D Center, Ourhome Ltd., Sungnam 462-120, Korea \\ ${ }^{3}$ Research Division of Food Industry Promotion, Korea Food Research Institute, \\ Seongnam 463-746, Korea
}

\begin{abstract}
This study was conducted to investigate the optimal conditions of collagen extraction from scales of yellowfin tuna (Thunnus albacares) using surface response methodology. Four independent variables of $\mathrm{NaOH}$ concentration and pretreatment fime in alkali pretreatment and enzyme concentration and treatment time in enzyme hydrolysis were used to predict a model equation for the collagen yield. The determinant coefficient $\left(\mathrm{R}^{2}\right)$ for the equation was 0.906 . The values of the independent variables for the maximum yield were $0.32 \mathrm{~N} \mathrm{NaOH}, 16.38 \mathrm{~h}$ alkali pretreatment time, $0.18 \%$ enzyme concentration, and $31.02 \mathrm{~h}$ enzyme treatment time. In the physicochemical properties of tuna scale collagen, sodium dodecyl sulfate-polyacrylamide gel electrophoresis of tuna scale collagen showed the same migration distances as that of calf skin collagen. The amide A, I, II, and III regions of tuna scale collagen in Fourier transform infrared measurements were shown in the peaks of $3,414 \mathrm{~cm}^{-1}$, $1,645 \mathrm{~cm}^{-1}, 1,553 \mathrm{~cm}^{-1}$, and $1,247 \mathrm{~cm}^{-1}$, respectively. The amount of imino acids in tuna scale collagen was $18.97 \%$ and the collagen denaturation temperature was $33^{\circ} \mathrm{C}$. The collagen solubility as a function of $\mathrm{NaCl}$ concentration decreased to $4 \% \mathrm{NaCl}(\mathrm{w} / \mathrm{v})$ and the collagen solubility as a function of $\mathrm{pH}$ was high at $\mathrm{pH} 2-4$ and sharply decreased from $\mathrm{pH} 4$ to $\mathrm{pH} 7$. Viscosity of the collagen solution decreased continuously until $30^{\circ} \mathrm{C}$ and this decreasing rate slowed in the temperature range of $35-50^{\circ} \mathrm{C}$.
\end{abstract}

Key words: Collagen, Yellowfin tuna, Thunnus albacares, Scale, Response surface methodology,

Physicochemical characteristics

\section{Introduction}

Collagen is a fibrous protein that composes 25$30 \%$ of the total protein in vertebrates. Collagen exists in almost all the tissues and organs of the skin, including cartilage, bone, muscle, blood vessels and supporting tissue, and internal organs to maintain structure (Piez, 1985). Collagen, which has recently been examined as a functional ingredient, has been used as a food additive in ham, sausage, and other foods to improve mouthfeel as well as in film formation, such as edible casings or films (Pearson, 1988). As a medicinal product, type II collagen

*Corresponding author: owlkim@pknu.ac.kr shows an ability to reduce pain by inhibiting the activity of $\mathrm{T}$ cells (Li et al., 2006). Furthermore, collagen can be as an edible condiment due to its efficiency of skin care ( $\mathrm{Li}$ et al., 2005). However, most collagen research has focused on animal sources of bovine and pork with little research on collagen from marine sources.

Marine sources for collagen have been examined by Nagai and Suzuki (2002). They isolated fish collagen from the epidermis of paper nautilus and the skin of puffer fish, and studied their physicochemical properties, such as molecular weight using sodium dodecyl sulfate-polyacrylamide gel electrophoresis (SDS-PAGE), peptide mapping, and denaturation temperature. Acid-soluble collagens were extracted from the skin of brownstripe red snapper (Jong- 
jareonrak et al., 2005) and skins of Nile perch (Muyonga et al., 2004). Their properties were studied by thermal denaturation temperature using differential scanning calorimetry, solubility, and amino acid analysis. Yoshimura et al. (2000) and Nomura et al. (2000) extracted collagen from the skin of great blue sharks (Prionace glauca) and investigated the physicochemical properties. Also, similar studies were carried out on collagen isolated from the skins of jellyfish and cuttlefish (Nagai et al., 2000, 2001). The collagen from the backbone of Seriola quinqueradiata was tested for various uses (Morimura et al., 2002). In the collagen studies of fish scales, collagen was extracted by using $0.5 \mathrm{M}$ acetic acid from carp scales (Kimura et al., 1991). Recently, the partial physicochemical properties of scale collagens from the red sea bream (Pagrus major), sardine (Sardinops melanostictus), and Japanese sea bass (Lateolabrax japonicus) were studied by Nagai et al. (2004). Ikoma et al. (2003) extracted type I collagens from scales of $P$. major and the Nile mouth breeder (Oreochromis niloticus) and investigated their properties. Ogawa et al. (2004) isolated collagens from bones and scales of the subtropical fish black drum (Pogonia cromis) and sheepshead seabream (Archosargus probatocephalus) and examined their biochemical properties. When collagen is isolated from the skin, scale, and other parts of fish, it is used as an ingredient in functional foods, condiments, and medicinal products. Fish collagen can be a viable replacement for the traditional bovine and pork gelatins, which are exposed to bovine spongiform encephalopathy or foot/mouth diseases (Yamauchi, 2002). Also, it can aid in religious dietary laws stating that the bovine or pork collagens cannot be used (Sadowska et al., 2003). Furthermore, collagen extraction from fish byproducts reduces environmental contamination and produces biofunctional proteins.

Tuna (skipjack and yellowfin) have been a staple fish and their harvesting amount is estimated at 4,060,000 MT per year (2007 World Capture Production of FAO Fisheries Department). Yellowfin tuna is mainly consumed as sashimi in sushi and canned foods, and most skipjack tuna is used for canned foods and hatsuobushi. However, many of the processing by-products such as skin, scale, and others induce environmental pollution. Therefore, the extraction of bioactive components from the byproducts is an efficient and economically advantageous means of recycling these waste products.

Response surface methodology (RSM), which shows the relationship between dependent variables and independent variables, has been used to determine the optimum extraction conditions for bioactive components (Edwards and Jutan, 1997). Using RSM, Cho et al. (2004, 2005) studied the optimization of gelatin extraction from shark (Isurus oxyrinchus) cartilage and yellowfin tuna skin. These studies demonstrated that RSM is an effective tool for investigating the optimum extraction conditions for producing gelatin.

The objectives of this research were to investigate the optimum conditions for extracting collagen from the scales of yellowfin tuna using RSM and to investigate the physicochemical properties of the resulting collagen. Its physicochemical properties are also compared with those of collagen from calf skin.

\section{Materials and Methods}

\section{Materials}

Yellowfin tuna (Thunnus albacares) scale was obtained from Dongwon Industries Co., Ltd. (Busan, Korea, 2006) and stored at $-18^{\circ} \mathrm{C}$ until use. Calf skin collagen and pepsin were purchased from SigmaAldrich Co. (St. Louis, MO, USA). The other chemicals used for this study were of analytical grade.

\section{Methods \\ Collagen extraction}

Collagen extraction was carried out by the method of Ogawa et al. (2004), with slight modification. Yellowfin tuna scale was homogenized for $3 \mathrm{~min}$ at $10,000 \times g$ (HB-201SF; Hanbaek Scientific Co., Seoul, Korea) with a homogenizer (CR-52F; SMT Co., Tokyo, Japan). The homogenized scale was washed and added into $0.1,0.2,0.3,0.4$, and $0.5 \mathrm{M} \mathrm{NaOH}$ to remove non-collagen proteins prior to shaking at $4^{\circ} \mathrm{C}$ for 6 to $30 \mathrm{~h}$ with $6 \mathrm{~h}$ intervals in a shaking incubator (NB-205v; N-BIOTEK, Tokyo, Japan). After alkali pretreatment, the alkali solution was removed via washing and neutralization. The neutralized sample solution was diluted to 10 times $(\mathrm{w} / \mathrm{v})$ with $0.04,0.12$, $0.20,0.28$, and $0.36 \%$ acetic acid solution, which was added with pepsin $(0.04-0.36 \%, w / v)$. Enzymatic hydrolysis was carried out at $10^{\circ} \mathrm{C}$ for 18 to $42 \mathrm{~h}$ with $6 \mathrm{~h}$ intervals in a shaking incubator at $200 \mathrm{rpm}$. Enzyme-treated samples were separated into extracted solution and residue using filter paper $(5 \mathrm{~A} 110 \mathrm{~mm}$; Advantec, Tokyo, Japan). Extracted solution was dialyzed with $25 \% \mathrm{NaCl}$ solution to make a $5 \%$ final concentration. Dialyzed solution was diluted with 10 times distilled water and centrifuged three or four 
Table 1. Experimental ranges and values of the independent variables in the central composite design for collagen processing from scale of yellowfin tuna (Thunnus albacares)

\begin{tabular}{lcccccc}
\hline \multirow{2}{*}{ Independent variables } & \multirow{2}{*}{ Symbol } & \multicolumn{5}{c}{ Ranges and levels } \\
\cline { 3 - 7 } & & -2 & -1 & 0 & 1 & 2 \\
\hline NaOH concentration (N) & $X_{1}$ & 0.1 & 0.2 & 0.3 & 0.4 & 0.5 \\
NaOH pretreatment time (hr) & $X_{2}$ & 6 & 12 & 18 & 24 & 30 \\
Enzyme concentration (\%) & $X_{3}$ & 0.04 & 0.12 & 0.2 & 0.28 & 0.36 \\
Hydrolysis time (hr) & $X_{4}$ & 18 & 24 & 30 & 36 & 42 \\
\hline
\end{tabular}

times at $10,000 \times g$ before drying. The whole procedure for collagen extraction was carried out at low temperatures to prevent heat denaturation of collagen.

\section{Experimental design and data analysis}

To determine the optimum extraction conditions, central composite design (CCD) (Box \& Wilson, 1951) was attempted in the experimental range (Table 1). Regression analysis on the response surface was carried out using SAS (version 9.01; SAS Institute, Cary, NC, USA). Four independent variables were set up and each variable was designed in the range of five values. Twenty-seven experimental points composed of 16 factorial points, 8 axial points, and 3 central points (Table 2) were designed. The important variables for collagen extraction were chosen based on the four independent variables of concentration and time for alkali and enzyme

treatments. That is, the independent variables were $\mathrm{NaOH}$ concentration $\left(\mathrm{N}, X_{1}\right)$, alkali pretreatment time $\left(\mathrm{h}, X_{2}\right)$, pepsin concentration $\left(\%, X_{3}\right)$, and pepsin treatment time $\left(\mathrm{h}, X_{4}\right)$. The ranges and levels were decided with five intervals based on the formula (1):

$$
\mathrm{x}_{i}=\frac{X_{i}-X_{0}}{\Delta X_{i}}
$$

where $\mathrm{x}_{i}$ is the coded value of the independent variable, $X_{i}$ is the real value of the independent variable, $X_{0}$ is the real central value of the independent variable, and $\Delta X_{i}$ is the range of the independent variable. The dependent variable was collagen yield $(Y, \%)$ (Table 2$)$. The central points and the ranges for the independent variables were set based on pre-experimental results (Table 1). The response surface model equation was obtained at the 95\% confidence level using the RSREG (response surface regression) procedure of SAS version 9.01:

$$
Y=\beta_{0}+\sum_{i=1}^{4} \beta_{i} X_{i}+\sum_{i=1}^{4} \beta_{i i} X_{i}^{2}+\sum_{i=1}^{3} \sum_{j=i+1}^{4} \beta_{i j} X_{i} X_{j}
$$

where $Y$ is the collagen yield (\%) of the dependent variable; $\beta_{0}$ is a constant; $\beta_{i}, \beta_{i i}$, and $\beta_{i j}$ are regression coefficients; and $X_{i}$ and $X_{j}$ are independent values. The response surface plots of the three-dimensional
Table 2. Central composite design and responses of the dependent variable for collagen processing from scale of yellowfin tuna (Thunnus albacares) to the

\begin{tabular}{|c|c|c|c|c|c|}
\hline \multirow{2}{*}{$\begin{array}{l}\text { Run } \\
\text { No. }\end{array}$} & \multicolumn{4}{|c|}{ Coded levels of variable } & \multirow{2}{*}{$\begin{array}{c}\text { Response } \\
Y(\%)\end{array}$} \\
\hline & $X_{1}$ & $X_{2}$ & $X_{3}$ & $X_{4}$ & \\
\hline 1 & -1 & -1 & -1 & -1 & 1.84 \\
\hline 2 & -1 & -1 & -1 & +1 & 4.82 \\
\hline 3 & -1 & -1 & +1 & -1 & 3.93 \\
\hline 4 & -1 & -1 & +1 & +1 & 2.19 \\
\hline 5 & -1 & +1 & -1 & -1 & 1.77 \\
\hline 6 & -1 & +1 & -1 & +1 & 2.24 \\
\hline 7 & -1 & +1 & +1 & -1 & 2.16 \\
\hline 8 & -1 & +1 & +1 & +1 & 1.88 \\
\hline 9 & +1 & -1 & -1 & -1 & 3.53 \\
\hline 10 & +1 & -1 & -1 & +1 & 3.93 \\
\hline 11 & +1 & -1 & +1 & -1 & 3.53 \\
\hline 12 & +1 & -1 & +1 & +1 & 3.34 \\
\hline 13 & +1 & +1 & -1 & -1 & 2.04 \\
\hline 14 & +1 & +1 & -1 & +1 & 2.79 \\
\hline 15 & +1 & +1 & +1 & -1 & 1.57 \\
\hline 16 & +1 & +1 & +1 & +1 & 2.36 \\
\hline 17 & -2 & 0 & 0 & 0 & 2.32 \\
\hline 18 & +2 & 0 & 0 & 0 & 2.36 \\
\hline 19 & 0 & -2 & 0 & 0 & 3.06 \\
\hline 20 & 0 & +2 & 0 & 0 & 1.37 \\
\hline 21 & 0 & 0 & -2 & 0 & 2.55 \\
\hline 22 & 0 & 0 & +2 & 0 & 1.45 \\
\hline 23 & 0 & 0 & 0 & -2 & 1.88 \\
\hline 24 & 0 & 0 & 0 & +2 & 3.57 \\
\hline 25 & 0 & 0 & 0 & 0 & 6.95 \\
\hline 26 & 0 & 0 & 0 & 0 & 6.28 \\
\hline 27 & 0 & 0 & 0 & 0 & 6.59 \\
\hline
\end{tabular}
independent variables

graph were drawn using Maple 7 (Waterloo Maple Inc., Waterloo, ON, Canada). When two independent variables were shown for collagen yield, the other two independent variables were fixed to the values under the optimum condition.

\section{SDS-PAGE}

SDS-PAGE was carried using a Mini-Protean 3 (Bio-Rad Laboratories, Hercules, CA, USA). The condition of the gel electrophoresis was slightly modified from the method of Laemmli (1970). For polyacrylamide gel, a $5 \%$ concentration of stacking gel and resolving gel were used. The $5 \mathrm{mg} / \mathrm{mL}$ of sample was equally mixed with the buffer, which contained $1 \mathrm{~mL}$ of $0.25 \mathrm{M}$ Tris- $\mathrm{HCl}$ (pH 6.8), $1.6 \mathrm{~mL}$ 
of $10 \% \mathrm{SDS}, 0.4 \mathrm{~mL}$ of $5 \%$ 2-mercaptoethanol, 3.2 $\mathrm{mL}$ of $20 \%$ glycerol, and $1 \mathrm{~mL}$ of $0.1 \%$ bromophenol blue. The mixed solution was heated at $100^{\circ} \mathrm{C}$ for 3 min. The $5 \mathrm{uL}$ of sample solution was injected to the gel, and then $20 \mathrm{~mA}$ gel current was flowed at ambient temperature for $2 \mathrm{~h}$. After gel electrophoresis, the gel was stained with $0.25 \%(\mathrm{w} / \mathrm{v})$ Coomassie brilliant blue R250. Calf skin was used as a marker protein for comparison.

\section{Amino acid analysis}

A $5 \mathrm{mg}$ collagen sample was weighed and $3 \mathrm{~mL}$ of $6 \mathrm{~N} \mathrm{HCl}$ was added before hydrolyzing at $110^{\circ} \mathrm{C}$ for $24 \mathrm{~h}$ in a dry bath. The hydrolyzed solution was vacuum-filtered with a glass filter $(0.5 \mu \mathrm{m})$ and vacuum-concentrated using a rotary vacuum evaporator (N-1N8; EYELA, Tokyo, Japan). The concentrated solution was made to $10 \mathrm{~mL}$ final volume with a sodium citrate phosphate buffer ( $\mathrm{pH}$ 2.2). The amino acid analysis was carried out using an automatic amino acid analyzer (L-8800; Hitachi, Tokyo, Japan).

\section{Fourier transform infrared (FT-IR) spectros- copy}

FT-IR spectroscopy was measured using a FT-IR spectrophotometer (IFS 88; Bruker, Ettlingen, Germany). Data were collected from 500 to 4,000 $\mathrm{cm}^{-1}$ with a $2 \mathrm{~cm}^{-1}$ data acquisition rate for collagens from yellowfin tuna scale and calf skin. Curve fitting was shown using Peakfit Software (SPSS Inc., Chicago, IL, USA).

\section{Viscosity measurement}

The viscosity of collagen from yellowfin tuna scale was measured using a slightly modified method of Kittiphattanabawon et al. (2005). Collagen was dissolved in $0.1 \mathrm{M}$ acetic acid solution to make a 500 $\mathrm{mL}$ final volume of a $0.03 \%$ collagen concentration. The solution was melted in a $60^{\circ} \mathrm{C}$ water bath (SB651; EYELA). A Brookfield Synchorolectic viscometer (Model II+; Brookfield Engineering Laboratories, Inc., Stoughton, MA, USA) was used at $30 \mathrm{rpm}$ with a 40 spindle number. The temperature was measured from $15^{\circ} \mathrm{C}$ to $50^{\circ} \mathrm{C}$, increasing at $5^{\circ} \mathrm{C} / \mathrm{min}$. The collagen solution was kept for $10 \mathrm{~min}$ at each temperature and the experiment was performed with three replications. The viscosity at each temperature was compared with the result at $15^{\circ} \mathrm{C}$.

\section{Solubility measurement}

Collagen solubility was measured using the method of Montero et al. (1991), with a slight modification. The final collagen concentrations were made to 3 and $6 \mathrm{mg} / \mathrm{mL}$ with $0.5 \mathrm{M}$ acetic acid solution, which was stirred at $4^{\circ} \mathrm{C}$ for $12 \mathrm{~h}$ to melt it. Collagen solubility at each $\mathrm{NaCl}$ concentration was measured. Each $5 \mathrm{~mL} \mathrm{NaCl}$ solution, which contained $0 \%, 2 \%, 4 \%, 6 \%, 8 \%, 10 \%$, or $12 \%(\mathrm{w} / \mathrm{v}) \mathrm{NaCl}$ in a $0.5 \mathrm{M}$ acetic acid solution, was mixed to a $5 \mathrm{~mL}$ collagen solution with a $6 \mathrm{mg} / \mathrm{mL}$ collagen concentration. Therefore, the final concentrations of each solution were $0 \%, 1 \%, 2 \%, 3 \%, 4 \%, 5 \%$, and $6 \%$, respectively. The above solution was stirred at $4{ }^{\circ} \mathrm{C}$ for $30 \mathrm{~min}$ and centrifuged at $4^{\circ} \mathrm{C}$ and $10,000 \times g$ for $30 \mathrm{~min}$. The protein concentration of the supernatant was measured by the method of Lowry et al. (1951) and bovine serum albumin was used as a standard. The relative solubilities of $\mathrm{NaCl}$ concentrations are shown in comparison with the value of the highest solubility. The effect of $\mathrm{pH}$ on collagen solubility was measured. The $\mathrm{pH}$ of an $8 \mathrm{~mL}$ collagen solution of 3 $\mathrm{mg} / \mathrm{mL}$ concentration was adjusted from 1 to 10 with $6 \mathrm{~N} \mathrm{NaOH}$ or $6 \mathrm{~N} \mathrm{HCl}$. The final volume was adjusted to $10 \mathrm{~mL}$ with distilled water. The solution was centrifuged at $4^{\circ} \mathrm{C}$ and $10,000 \times g$ for $30 \mathrm{~min}$. The protein concentrations were determined as described previously.

\section{Measurement of collagen denaturation tem- perature}

Collagen denaturation temperature, calculated using a modified method of Kimura et al. (1988), was determined by measuring its viscosity. After making $5 \mathrm{~mL}$ of $0.03 \%$ collagen concentration, the collagen viscosity was measured using an Ostwald-Fenske viscometer. Viscosity of the collagen solution was measured from $20^{\circ} \mathrm{C}$ to $50^{\circ} \mathrm{C}$ with $3^{\circ} \mathrm{C}$ intervals. Each solution temperature was kept for $10 \mathrm{~min}$ in a water bath (SB-651; EYELA). Collagen denaturation temperature $\left(T_{d}\right)$ was determined to be the temperature at $50 \%$ of the initial measured value.

\section{Results and Discussion}

\section{Statistical analysis on collagen extraction}

To optimize collagen processing from scales of yellowfin tuna, 27 experimental points were set. The results reported as collagen yield $(Y, \%)$ are shown in Table 2. From the data, the second-order model equation was obtained using the RSREG procedure of SAS software. The significance tests on all coefficients for the first-order terms $\left(X_{1}, X_{2}, X_{3}\right.$, and $\left.X_{4}\right)$, the second-order terms $\left(X_{11}, X_{22}, X_{33}\right.$, and $\left.X_{44}\right)$, and cross-products were evaluated using $t$-statistics, and their results are shown in Table 3. 
Table 3. Estimated coefficients of the fitted quadratic polynomial equation for the response of $\mathrm{Y}$ (yield, \%) based on t-statistic

\begin{tabular}{lrrrr}
\hline Parameter $^{\mathrm{a}}$ & $\begin{array}{c}\text { Parameter } \\
\text { estimate }\end{array}$ & $\begin{array}{c}\text { Standard } \\
\text { error }\end{array}$ & T-value & P-value \\
\hline Intercept & 6.6067 & 0.4036 & 16.37 & $<.0001$ \\
$X_{1}$ & 0.0975 & 0.1427 & 0.68 & 0.5074 \\
$X_{2}$ & -0.5700 & 0.1427 & -3.99 & 0.0018 \\
$X_{3}$ & -0.1750 & 0.1427 & -1.23 & 0.2435 \\
$X_{4}$ & 0.2733 & 0.1427 & 1.92 & 0.0795 \\
$X_{1} X_{1}$ & -0.9958 & 0.1513 & -6.58 & $<.0001$ \\
$X_{1} X_{2}$ & -0.0525 & 0.1748 & -0.30 & 0.7690 \\
$X_{2} X_{2}$ & -0.0271 & 0.1513 & -6.79 & $<.0001$ \\
$X_{1} X_{3}$ & -0.0613 & 0.1748 & -0.35 & 0.7320 \\
$X_{3} X_{2}$ & 0.0163 & 0.1748 & 0.09 & 0.9274 \\
$X_{3} X_{3}$ & -0.0808 & 0.1513 & -7.14 & $<.0001$ \\
$X_{4} X_{1}$ & 0.0200 & 0.1747 & 0.11 & 0.9108 \\
$X_{4} X_{2}$ & 0.0175 & 0.1747 & 0.10 & 0.9219 \\
$X_{3} X_{4}$ & -0.3763 & 0.1747 & -2.15 & 0.0524 \\
$X_{4} X_{4}$ & -0.8996 & 0.1513 & -5.94 & $<.0001$ \\
\hline
\end{tabular}

${ }^{\mathrm{a}} X_{1}, X_{2}, X_{3}$, and $X_{4}$ mean $\mathrm{NaOH}$ concentration $(\mathrm{N})$, alkali pretreatment time (hr), enzyme concentration (\%), and enzyme treatment time (hr), respectively.

While $X_{1}(P=0.5074), X_{3} \quad(P=0.2435)$, and $X_{4}$
$(P=0.0795)$ were not significant $(P>0.05), \quad X_{2}$ $(P=0.0018)$ was significant $(P<0.05)$. While all the second-order terms were significant $(P<0.01)$, all cross-products were not $(P>0.05)$.

The reaction model equation of the surface response method obtained after eight terms that were not significant at $95 \%$ were removed (Table 4 ).

The determinant coefficient $\left(\mathrm{R}^{2}\right)$ on collagen yield was $0.906(P=0.0004)$. The reason for the high determinant coefficient and significance was probably due to the central points and ranges that were chosen by pre-experimental data. The second-order model equation for collagen yield $(Y, \%)$ was evaluated using analysis of variance (ANOVA) (Table 5). In the ANOVA results, the first-order terms $\left(X_{1}, X_{2}, X_{3}\right.$, and $\left.X_{4} ; P=0.0101\right)$ and the secondorder terms $\left(X_{11}, X_{22}, X_{33}\right.$, and $\left.X_{44} ; P<0.0001\right)$ were significant at a significance level of $95 \%$, except for cross-product terms $(P=0.58)$. The regression was significant at $P<0.01$ and the model equation for the dependent variable $(Y, \%)$ was shown to be significant at a $95 \%$ significance level due to the lack of fit (Table 4).

Table 4. Analysis of variance (ANOVA) for response of the dependent variable (Y, yield $(\%)$ )

\begin{tabular}{|c|c|c|c|c|c|}
\hline Sources & $\mathrm{DF}^{\mathrm{a}}$ & $S S^{a}$ & $\mathrm{MS}^{\mathrm{a}}$ & F-value & P-value \\
\hline \multicolumn{6}{|l|}{ Regression } \\
\hline Linear & 4 & 10.55 & 0.17 & 5.40 & 0.0101 \\
\hline Quadratic & 4 & 43.29 & 0.70 & 22.15 & $<.0001$ \\
\hline Cross-product & 6 & 2.38 & 0.04 & 0.81 & 0.5795 \\
\hline Model & 14 & 56.23 & 0.91 & 8.22 & 0.0004 \\
\hline \multicolumn{6}{|l|}{ Residual } \\
\hline Lack of fin & 10 & 5.64 & 0.56 & 5.01 & 0.18 \\
\hline Pure error & 2 & 0.22 & 0.11 & - & - \\
\hline Total error & 12 & 5.86 & 0.49 & - & - \\
\hline Total & 26 & 62.09 & & - & - \\
\hline \multicolumn{6}{|l|}{ Factors $^{b}$} \\
\hline$X_{1}$ & 5 & 21.49 & 4.30 & 8.80 & 0.0010 \\
\hline$X_{2}$ & 5 & 30.36 & 6.07 & 12.43 & 0.0002 \\
\hline$x_{3}$ & 5 & 27.99 & 5.60 & 11.46 & 0.0003 \\
\hline$X_{4}$ & 5 & 21.33 & 4.27 & 8.73 & 0.0011 \\
\hline
\end{tabular}

${ }^{\mathrm{a}} \mathrm{DF}, \mathrm{SS}$ and MS stand for degrees of freedom, sum of square and mean square, respectively.

${ }^{\mathrm{b}} X_{1}, X_{2}, X_{3}$, and $X_{4}$ mean $\mathrm{NaOH}$ concentration $(\mathrm{N})$, alkali pretreatment time (hr), enzyme concentration (\%), and enzyme treatment time (hr), respectively.

Table 5. Optimal conditions of collagen processing from scale of yellowfin tuna (Thunnus albacares)

\begin{tabular}{cccccc}
\hline \multirow{2}{*}{ Dependent variable } & \multirow{2}{*}{ Independent variables $^{\mathrm{a}}$} & \multicolumn{2}{c}{ Critical value } & \multirow{2}{*}{ Predicted yield (\%) } & Stationary point \\
\cline { 3 - 4 } & $X_{1}$ & 0.06 & 00.32 & & Maximum \\
$Y($ Yield, \%) & $X_{2}$ & -0.27 & 16.38 & $6.72 \%$ & \\
& $X_{3}$ & -0.11 & 00.18 & & \\
& $X_{4}$ & 0.17 & 31.02 & & \\
\end{tabular}

${ }^{\mathrm{a}} X_{1}, X_{2}, X_{3}$, and $X_{4}$ mean $\mathrm{NaOH}$ concentration $(\mathrm{N})$, alkali treatment time (hr), enzyme concentration (\%), and enzyme pretreatment time (hr), respectively. 


\section{Optimization of collagen extraction}

CCD (Box \& Wilson, 1951) was used to investigate the optimum condition of collagen extraction from scales of yellowfin tuna. The four independent variables were $\mathrm{NaOH}$ concentration $\left(0.3 \mathrm{~N}, X_{1}\right)$ and pretreatment time $\left(18 \mathrm{~h}, X_{2}\right)$, and pepsin concentration $\left(0.2 \%, X_{3}\right)$ and treatment time $\left(30 \mathrm{~h}, X_{4},\right)$. Their central points and the ranges were determined by preexperimental results (Table 1). From the RSM results, the coded and uncoded values at the optimum levels are shown in Table 5.

Based on the results of the RSREG procedure, all the eigenvalues are negative, showing that the equation has a maximum value. The coded values at the optimum levels for maximum collagen extraction from yellowfin tuna scale were $\mathrm{x}_{1}=0.06, \mathrm{x}_{2}=-0.27$, $\mathrm{x}_{3}=-0.11$, and $\mathrm{x}_{4}=0.17$. That is, the optimum condition for maximum collagen extraction was $0.32 \mathrm{~N}$ $\mathrm{NaOH}$ concentration $\left(X_{1}\right), 16.38 \mathrm{~h}$ alkali pretreatment time $\left(X_{2}\right), 0.18 \%$ pepsin concentration $\left(X_{3}\right)$, and 31.02 $\mathrm{h}$ pepsin treatment time $\left(X_{4}\right)$ (Fig. 1).
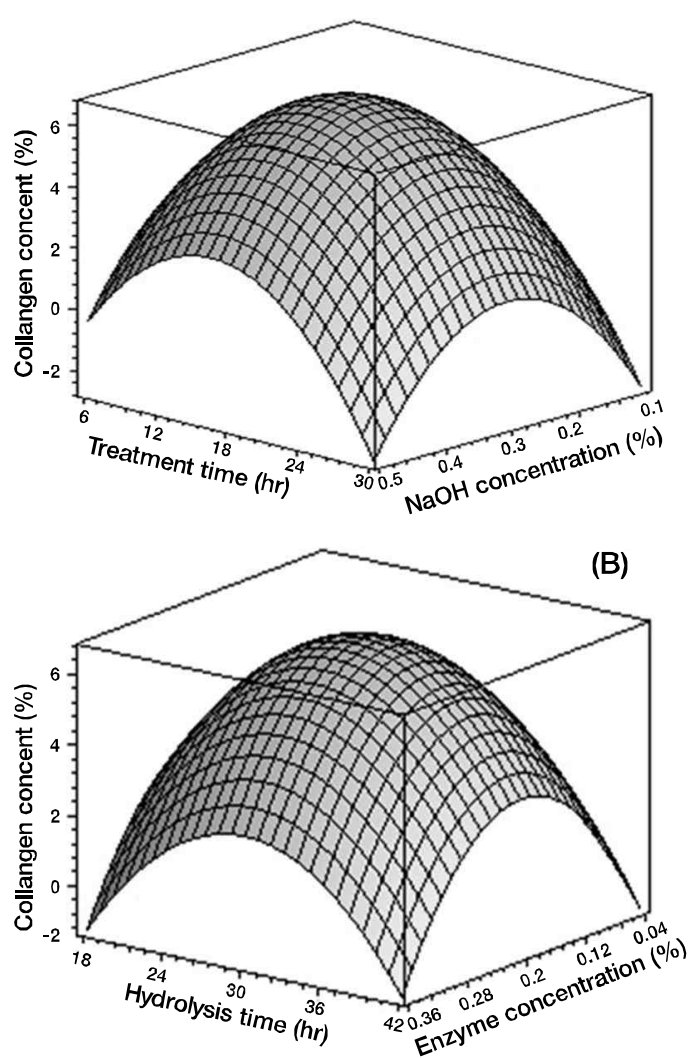

Fig. 1. Response surface plots for optimization of collagen extraction from scale of Yellowfin tuna scale. $Y, X_{1}, X_{2}, X_{3}$, and $X_{4}$ stand for collagen content $(\%), \mathrm{NaOH}$ concentration $(\mathrm{N})$, alkali pretreatment time (hr), enzyme concentration (\%), and hydrolysis time (hr), respectively.
Under the above conditions, the expected collagen yield $(Y$, yield $(\%))$ was $6.72 \%$ and the experimental collagen yield was $6.93 \%$. The extracted collagen yield was similar to the expected collagen yield.

The effects of the independent variables $\left(X_{1}, X_{2}, X_{3}\right.$, and $\left.X_{4}\right)$ on collagen yield $(Y)$ were drawn as threedimensional graphs using Maple 7 (Fig. 1). The relationship between alkali concentration and pretreatment time on collagen yield is shown in Fig. 1a and the relationship between pepsin concentration and treatment time on collagen yield is given in Fig. 1b. Both graphs show that the collagen yield increased as coded values were close to zero.

\section{SDS-PAGE of collagen}

The patterns of SDS-PAGE for yellowfin tuna collagen and calf skin collagen are shown in Fig. 2.

Calf skin collagen is composed of an $\alpha_{1}$-chain and an $\alpha_{2}$-chain. Type I collagen consists of two identical $\alpha_{1}$ - and $\alpha_{2}$-chains (Wong, 1989; Burghagen, 1999) and a $\beta$-component (cross-linked dimer of $\alpha$-chains) and $\gamma$-component (cross-linked trimer of $\alpha$-chains). Giraud-Guille et al. (2000) reported that the molecular weights of $\alpha_{1}, \alpha_{2}, \beta$, and $\gamma$ were 93, 93, 186, and $279 \mathrm{kDa}$, respectively. When compared to calf skin

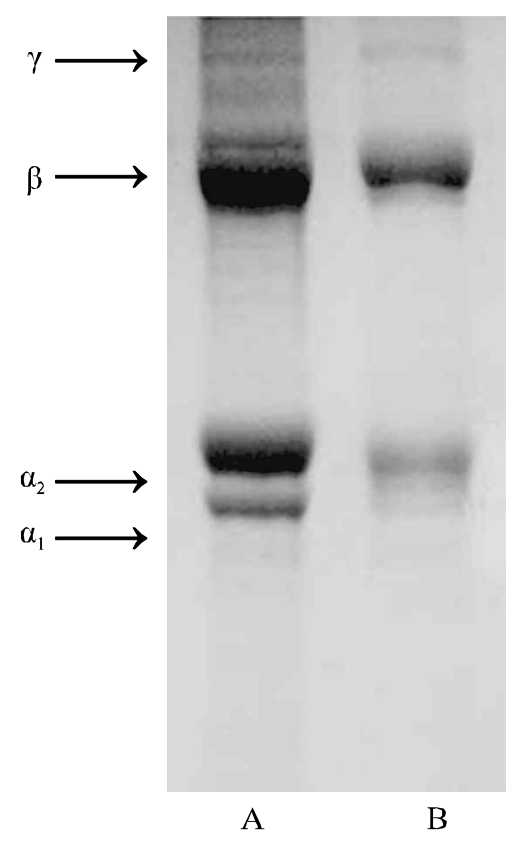

Fig. 2. SDS-PAGE patterns of collagen from scale of yellowfin tuna (Thunnus albacares) and calf skin. A; collagen from calf skin, B; collagen from scales of yellowfin tuna. The 5\% separating gel and 4\% stacking gel were used for eletrophoretic analysis. Loading volume of sample solution is $5.0 \mathrm{mg} / \mathrm{mL}$. Calf skin collagen was used as mobility maker of $\alpha, \beta$ and $\gamma$-chain components. 
collagen, yellowfin tuna scale collagen had an $\alpha_{1}$ chain, an $\alpha_{2}$-chain, a $\beta$-chain, and a $\gamma$-chain, and their $\alpha_{1}$ - and $\alpha_{2}$-chains were less dense.

\section{Amino acid composition of collagen}

The amino acid composition of collagen from yellowfin tuna scale and calf skin collagen is shown in Table 6.

Table 6. Amino acid composition of collagens from yellowfin tuna (Thunnus albacares) scale and calf skin

$(\%)$

\begin{tabular}{lcc}
\hline \multirow{2}{*}{ Amino acids } & \multicolumn{2}{c}{ Collagen type } \\
\cline { 2 - 3 } & Calf skin & Yellowfin tuna scale \\
\hline Hydroxyproline & 9.06 & 7.43 \\
Aspartic acid & 5.11 & 6.83 \\
Threonine & 1.85 & 1.40 \\
Serine & 2.85 & 2.45 \\
Glutamic acid & 10.69 & 11.20 \\
Proline & 10.88 & 11.54 \\
Glycine & 16.28 & 14.44 \\
Alanine & 8.12 & 8.65 \\
Valine & 2.27 & 2.25 \\
Isoleucine & 1.37 & 1.84 \\
Leucine & 2.86 & 3.50 \\
Tyrosine & 0.48 & 0.17 \\
Phenylalanine & 1.84 & 1.59 \\
Lysine $_{\text {Histidine }}^{\text {Arginine }}$ & 0.27 & 0.53 \\
Cysteine & 1.96 & 2.31 \\
Imino acids $^{a}$ & 4.19 & 4.91 \\
\hline
\end{tabular}

${ }^{\mathrm{a}}$ Imino acids mean proline and hydroxyproline.

The amount of hydroxyproline residue for collagen from yellowfin tuna scales was $7.43 \%$, which was lower than that of calf skin collagen $(9.06 \%)$. However, the amount of proline residue for collagen from yellowfin tuna scales was $11.54 \%$, which was higher than that of calf skin collagen (10.88\%). Glycine was the most prevalent amino acid in both calf and yellowfin tuna scale collagens at $16.28 \%$ and $14.44 \%$, respectively. The amount of hydroxyproline has been known to affect rheological properties, including gel strength. Gel produced from collagen peptide was reported to have better quality with a higher amount of hydroxyproline (Gilsenan \& RossMurphy, 2000; Gómez-Guillén et al., 2002). Therefore, the residual amounts of proline and hydroxyproline are thought to be important for collagen peptide quality.

\section{FT-IR}

FT-IR spectra for collagens from yellowfin tuna scales and for calf skin are shown in Fig. 3.
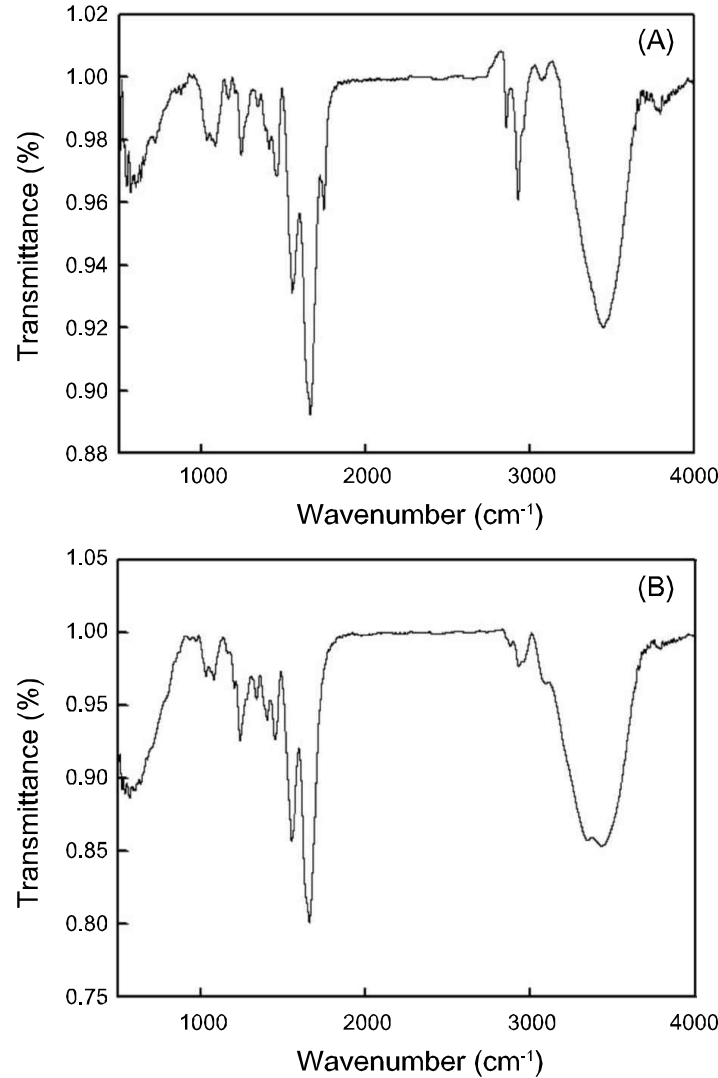

Fig. 3. Fourier transform infrared spectra of collagen from yellowfin tuna scale (A) and calf skin (B).

The regions of amide A, I, II, and III in the FT-IR spectrum are known to be associated with the structure of polypeptides (Jackson et al., 1995). The amide A band $\left(3,400-3,440 \mathrm{~cm}^{-1}\right)$ is known to associate with $\mathrm{N}-\mathrm{H}$ stretching vibration. The amide III band $\left(1,600-1,660 \mathrm{~cm}^{-1}\right)$ is related to stretching vibrations of the carbonyl group in peptides, and it is used to determine the secondary structure of proteins. Amide A $\left(1,550 \mathrm{~cm}^{-1}\right)$ is related to N-H bending and C-N stretching. Amide III $\left(1,320-1,220 \mathrm{~cm}^{-1}\right)$ is shown in C-N stretching and $\mathrm{N}-\mathrm{H}$ stretching in collagen triple helical conformations (Jakobsen et al., 1983; Muyonga et al., 2004). In this study, the respective regions of amide A, I, II, and III for collagen from scales of yellowfin tuna and calf skin collagen were $3,435 \mathrm{~cm}^{-1}$ and $3,414 \mathrm{~cm}^{-1}, 1,652 \mathrm{~cm}^{-1}$ and $1,645 \mathrm{~cm}^{-1}, 1,554 \mathrm{~cm}^{-1}$ and $1,553 \mathrm{~cm}^{-1}$, and 1,240 $\mathrm{cm}^{-1}$ and $1,247 \mathrm{~cm}^{-1}$, showing the similar peak wavelengths. In the results of Muyonga et al. (2004), collagen from the skin of young Nile perch showed $3,434,1,650,1,542$ and $1,235 \mathrm{~cm}^{-1}$ for the A, I, II, and III amide regions, respectively. Collagen from the adult skin of Nile perch had peaks at 3,458, 1,654, 
1,555 , and $1,238 \mathrm{~cm}^{-1}$ for the A, I, II, and III amide regions, respectively

\section{Collagen viscosity}

A concentration of $0.04 \%(\mathrm{w} / \mathrm{v})$ collagen was dissolved in distilled water at $60^{\circ} \mathrm{C}$. The viscosity of $0.04 \%(\mathrm{w} / \mathrm{v})$ collagen solution from scales of yellowfin tuna constantly decreased until $32^{\circ} \mathrm{C}$ and this decreasing rate slowed from $35^{\circ} \mathrm{C}$ to $50^{\circ} \mathrm{C}$ (Fig. $4)$.

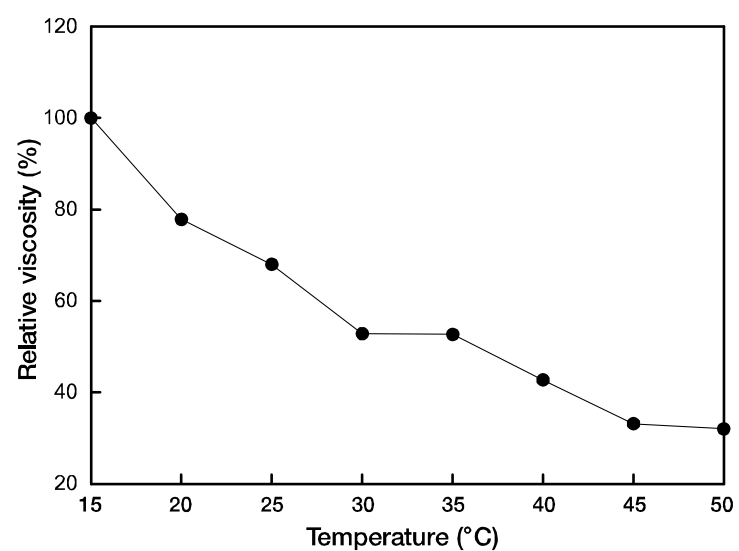

Fig. 4. Relative viscosity at different temperatures of the collagen solution of scale of yellowfin tuna (Thunnus albacares).

A high-temperature treatment induces the breakage of hydrogen bonding in gelatin structures (Wong, 1989). Changes in the gelatin structure during heating affects its viscosity (Nagai et al., 1999; Nagai \& Suzuki, 2000, 2002). Kittiphattanabawon et al. (2005) reported that the viscosities for collagens of bones and skins of bigeye snapper decreased constantly until $30^{\circ} \mathrm{C}$ and this decreasing rate was reduced in the temperature range of $35-50^{\circ} \mathrm{C}$. Also, the changes in gelatin viscosity for jellyfish showed a similar tendency as those of collagens of the bones and skins of bigeye snappers.

\section{Collagen solubility}

The effects of $\mathrm{NaCl}$ concentration on collagen solubility are shown in Fig. 5.

Solubility of collagen from scales of yellowfin tuna slowly decreased until $4 \%(\mathrm{w} / \mathrm{v}) \mathrm{NaCl}$. After that, its solubility slowly increased with $\mathrm{NaCl}$ concentration. An increase in ionic strength causes a reduction in protein solubility via an enhanced hydrophobichydrophobic interaction between protein chains and the competition for water of ionic salts, leading to the induced protein precipitation (Vojdani, 1996; Jongjareonrak et al., 2005).

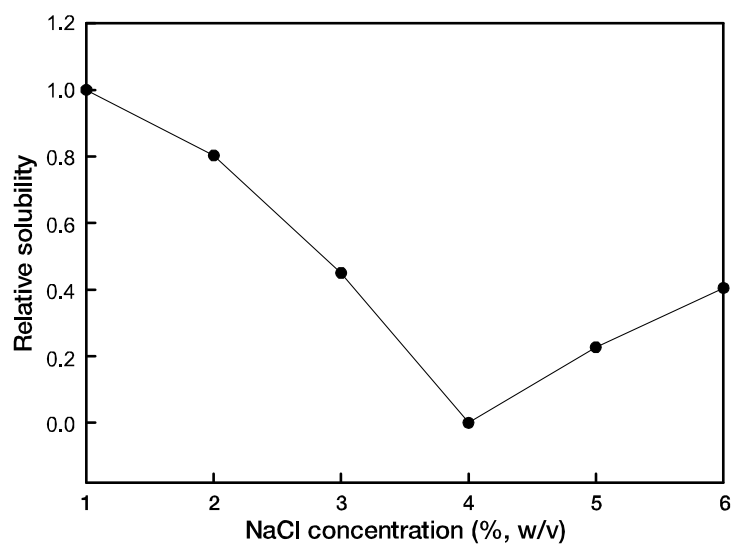

Fig. 5. Solubility in $0.5 \mathrm{M}$ acetic acid on $\mathrm{NaCl}$ concentration of the collagen obtained from scale of yellowfin tuna (Thunnus albacares).

In studies on collagen solubility in several $\mathrm{NaCl}$ concentrations on other fish, Kittiphattanabawon et al (2005) reported that acid-soluble collagens from the skins and bones of the bigeye snapper showed almost the same solubility in $0-3 \% \mathrm{NaCl}$ concentration. In a high $\mathrm{NaCl}$ concentration, its decreased solubility is thought to be due to salting out. That is, a higher $\mathrm{NaCl}$ concentration in a protein solution induces its lower solubility.

The effects of $\mathrm{pH}$ on the solubility of collagen from the scales of yellowfin tuna are shown in Fig. 6.

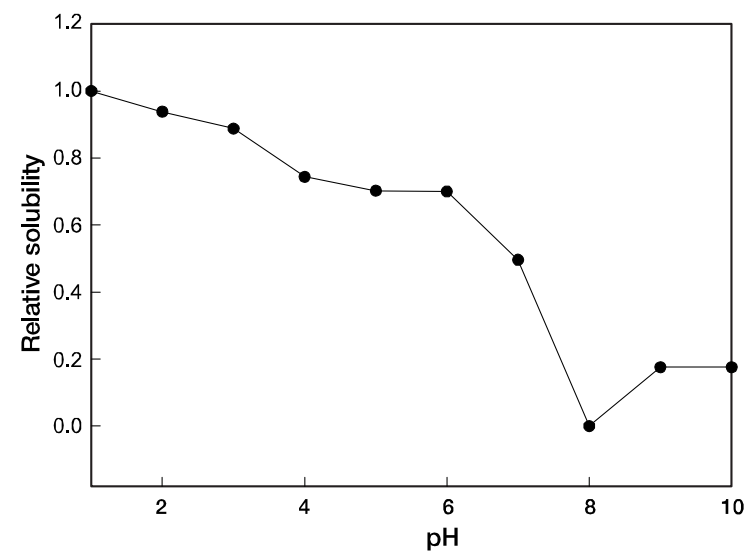

Fig. 6. Solubility in $0.5 \mathrm{M}$ acetic acid on $\mathrm{pH}$ of the collagen solution from scale of yellowfin tuna (Thunnus albacares).

Collagen solubility was highest at $\mathrm{pH} 1$ and it slowly decreased in the range of $\mathrm{pH} 2-6$. Then, it sharply decreased in the range of $\mathrm{pH}$ 6-8. Collagen solubility slowly increased in the range of $\mathrm{pH}$ 9-10. In general, collagen shows high solubility under acidic conditions and the different solubilities of 
proteins at different $\mathrm{pH}$ levels are thought to be due to their different isoelectric points (pIs). When the $\mathrm{pH}$ of a protein solution is higher or lower than its pI, protein solubility increases due to the increased repulsion of protein residuals. In the opposite situation at the $\mathrm{pI}$, hydrophobic interactions increase and the total charge of a protein molecule is close to zero; so protein aggregation is induced (Wong, 1989).

The solubilities of collagens from bigeye snapper bone and skin have been reported to be highest at $\mathrm{pH}$ 2 and 5, respectively. Their solubilities sharply decreased after passing $\mathrm{pH} 5$ and $\mathrm{pH} 6$, and their solubilities were lowest at $\mathrm{pH} 7$ and 8 , respectively. The solubilities were similar to those reported in this study (Kittiphattanabawon et al., 2005).

\section{Collagen denaturation temperature $\left(T_{d}\right)$}

The denaturation temperature $\left(T_{d}\right)$ of yellowfin tuna scale collagen is shown in Fig. 7.

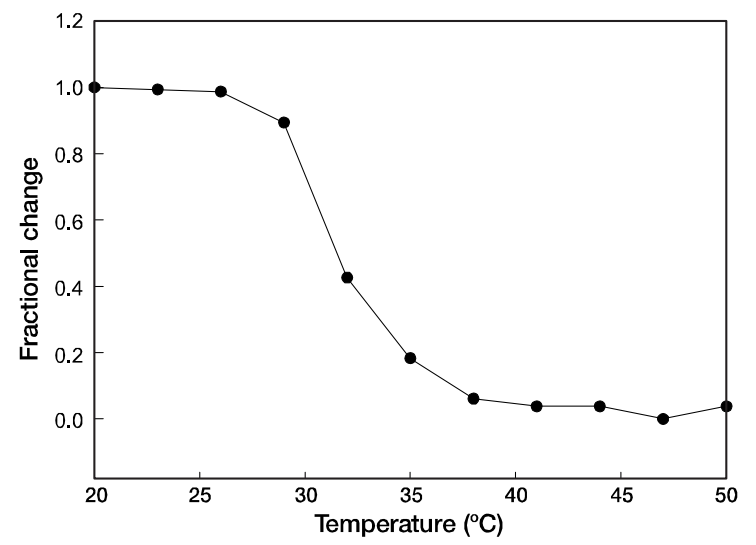

Fig. 7. Thermal denaturation curves determined by measuring the viscosity of collagen from scale of yellowfin tuna (Thunnus albacares) solution of $0.1 \mathrm{M}$ acetic acid.

The collagen denaturation temperature $\left(T_{d}\right)$ of yellowfin tuna scale collagen was $31^{\circ} \mathrm{C}$, which was similar to that of calf skin collagen $\left(32^{\circ} \mathrm{C}\right)$. Kimura et al. (1988) reported that the $T_{d} S$ of collagens from carp, eel, and mackerel muscles were $32.5^{\circ} \mathrm{C}, 30.2^{\circ} \mathrm{C}$, and $26.9^{\circ} \mathrm{C}$, respectively, and imino acid concentrations were $43.2 \%, 40.2 \%$, and $41.1 \%$, respectively, showing that protein denaturation temperatures are higher with increasing concentrations of imino acids. Collagen denaturation temperatures of other fish were $10^{\circ} \mathrm{C}$ for hake, $15^{\circ} \mathrm{C}$ for Atlantic cod, $16.8^{\circ} \mathrm{C}$ for Alaska pollock, $25^{\circ} \mathrm{C}$ for bullhead shark, $26.5^{\circ} \mathrm{C}$ for Japanese seabass, and $28^{\circ} \mathrm{C}$ for the ocellate puffer (Nishimoto et al., 2005). The $T_{d}$ for tuna collagen was higher than those of other fish collagens. One possible explanation is that tuna collagen has higher amounts of imino acids than those of other fish. Imino acids (proline and hydroxyproline), which are involved in heat stability, are important factors for industrial application.

\section{Acknowledgments}

This work was supported by the Pukyong National University Research Fund in 2007.

\section{References}

Box GEP and Wilson KB. 1951. On the experimental attainment of optimum conditions. J Royal Stati. Soci $13,1-45$.

Burghagen. 1999. Collagen. In H. D. Belitz \&W. Grosch (Eds.), Food chem.. 2, 540-547. Berlin: Springer.

Cho SM, Kwak KS, Park DC, Gu Y.S, Ji CI, Jang DH, Lee YB, and Kim SB. 2004. Processing optimization and functional properties of gelatin from shark (Isurus oxyrinchus) cartilage. Food Hydrocolloids 18, 573579.

Cho SM, Gu YS, and Kim SB. 2005. Extracting optimization and physical properties of yellowfin tuna (Thunnus albacares) skin gelatin compared to mammalian gelatins. Food Hydrocolloids 19, 221-229.

Edwards IM and Jutan A. 1997. Optimization and control using response surface methods. Computer Chem Engin 21, 441-453.

Gilsenan PM and Ross-Murphy SB. 2000. Rheological characterization of gelatins from mammalian and marine sources. Food Hydrocolloids 14, 191-195.

Giraud-Guille MM, Besseau L, Chopin C, Durand P and Herbage D. 2000. Structural aspects of fish skin collagen which forms ordered arrays via liquid crystalline states. Biomaterials 21, 899-906.

Gómez-Guillén MC, Turnay J, Fernández-Díaz MD, Ulmo N, Lizaebe MA and Montero P. 2002. Structural and physical properties of gelatin extracted from different marine species. Food Hydrocolloids 16, 25-34.

Ikoma T, Kobayashi H, Tanaka J, Walsh D and Mann S. 2003. Physical properties of type I collagen extracted from fish scales of Pagrus major and Oreochromis niloticas. Int J Biolo Macromoleculer 32, 199-204.

Jackson M, Choo LP, Watson PH, Halliday WC and Mantsch HH. 1995. Beware of connective tissue proteins: assignment and implications of collagen absorptions in infrared spectra of human tissues. Biochimi Biophysics Acta 1270, 1-6.

Jakobsen, R.L., Brown, L.L., Hutson, T.B., Fink, D.J. and Veis, A. 1983. Intermolecular interactions in collagen self-assembly as revealed by Fourier transform in- 
frared spectroscopy. Science, 220, 1288-1290.

Jongjareonrak A, Benjakul S, Visessanguan W, Nagai T and Munehiko Tanka. 2005. Isolation and characterisation of acid and pepsin-solubilised collagens from the skin of Brownstripe red snapper (Lutjanus vitta). Food Chem 93, 475-484.

Kimura S, Miyaushi Y and Uchida N. 1991. Scale and bone type I collagen of carp (Cyprinus carpio). Comp Biochem. Physio 99B, 473-476.

Kimura S, Zhu XP, Matsui R, Shijoh M and Takamizawa S. 1988. Characterization of fish muscle type I collagen. J Food Sci 53, 1315-1318.

Kittiphattanabawon P, Benjakul S, Visessanguan W, Nagai $T$ and Tanaka M. 2005. Characerisation of acidsoluble collagen from skin and bond of bigeye snapper (Priacanthus tayenus). Food Chem 89, 363372.

Laemmli UK. 1970. Cleavage of structural proteins during the assembly of the head of bacteriophage T4. Nature 227, 680-685.

Li R, Li X and Li Z. 2006. Altered collagen II peptides inhibited T-cell activation in rheumatoid arthritis. Clin Immunol 118, 317-323.

Li YG, Fukunaga S, Takenouchi K and Nakamura F. 2005. Comparative study of the physiological properties of collagen, gelatin and collagen hydrolysate as cosmetic materials. Int J Cosmet Sci 27, 101-106.

Lowry OH, Rosebrough NJ, Farr AL and Randall RJ. 1951. Protein measurement with Folin phenol reagent. J Biologic Chem 193, 256-275.

Montero P, Jimennez-Colmenero F and Borderias J. 1991. Effect of $\mathrm{pH}$ and the presence of $\mathrm{NaCl}$ on some hydration properties of collagenous material from trout (Salmo irideus Gibb) muscle and skin. J Sci Food Agric 54, 137-146.

Morimura S, Nagata H, Uemura Y, Fahmi Y, Shigematsu $\mathrm{T}$ and Kida K. 2002. Development of an effective process for utilization of collagen from livestock and fish waste. Process Biochem 37, 1403-1412.

Muyonga JH, Cole C, GB and Duodu KG. 2004. Characterization of acid soluble collagen from skins of young and adult Nile perch (Lates niloticus). Food Chem 85, 81-89.

Nagai T, Izumi M and Ishii M. 2004. Fish scale collagen, preparation and partial characterization. Int J Food Sci Technol 39, 239-244.

Nagai T, Ogawa T, Nakamura T, Ito Tatsumi, Nakagawa H, Fujiki K, Nakao M and Yano T. 1999. Collagen of edible jellyfish exumbrella. J Sci Food Agric 79, 855858.

Nagai T and Suzuki N. 2000. Isolation of collagen from fish waste material-skin, bone and fin. Food Chem 68,
277-281

Nagai T and Suzuki N. 2002. Preparation and partial characterization of collagen from paper nautilus (Argonauta argo, Linnaeus) outer skin. Food Chem 76, 149-153.

Nagai T, Worawattanamateekul W, Susuki N, Nakamura T, Ito T, Nakao $\mathrm{M}$ and Yano T. 2000. Isolation and characterization of collagen from rhizostomous jellyfish (Rhopilema asamushi). Food Chem 70, 205 208.

Nagai T, Yamashita E, Taniguchi K, Kanamori N and Suzuki N. 2001. Isolation and characterization of collagen from the outer skin waste material of cuttlefish (Sepia lycidas). Food Chem 72, 425-429.

Nishimoto M, Sakamoto R, Misuta S and Yoshinaka R. 2005. Identification and characterization of molecular species of collagen in ordinary muscle and skin of the Japanese flounder Paralichthys olicaceus. Food Chem 90, 151-156.

Nomura Y, Toki S, Ishii Y and Shirai KS. 2000. The physicochemical property of shark type I collagen gel and membrane. J Agric Food Chem 48, 2028-2032.

Ogawa M, Portier RJ, Moody MW, bell J, Schexnayder MA and Losso JN. 2004. Biochemical properties of bone and scale collagens isolated from the subtropical fish black drum (Pogonia cromis) and sheepshead seabream (Archosargus probatocephalus). Food Chem 88, 495-501.

Pearson AM. 1988. Collagen as a food: Advances in meat research: (vol. 4). An AVI Book, New York.

Piez KA. 1985. Collagen in: JI. Kroschwitz (Ed), Encyclopedia of Polymer Science and Engineering, Wiley, New York, USA: 699-727.

Sadowska M, Kolodziejska I and Niecikowska C. 2003. Isolation of collagen from the skin of Baltic cod (Gadus morhua). Food Chem 81, 257-262.

Vojdani F. 1996. Solubility. In GM. Hall (Ed), Methods of Testing Protein Functionality Great Britain: St Edmundsbury, 11-60.

Wong DWS. 1989. Mechanism and Theory in Food Chemistry. New York, USA: Van Nostrand Reinhold.

Yamauchi K. 2002. Bovine Spongiform Encephalopathy and People. Iwanami Press, Tokyo, Japan

Yoshimura K, Terashima M, Hozan D and Shirai K. 2000. Preparation and dynamic viscoelasticity characterization of alkali-solubilized collagen from shark skin. J Agric Food Chem 48, 685-690.

(Received 31 March 2010; Revised 20 May 2010; Accepted 26 May 2010) 